Info Artikel:

\title{
PENINGKATAN AKTIVITAS DAN HASIL BELAJAR PENDIDIKAN AGAMA ISLAM PESERTA DIDIK KELAS IX SMPMELALUI PEMBELAJARAN KOOPERATIF TIPE JIGSAW
}

\author{
Irmawati
}

SMP. N 2 Palupuh

\begin{abstract}
Abstratc
Penelitian ini bertujuan untuk meningkatkan aktivitas belajar dan hasil belajar peserta didik dalam pembelajaran Pendidikan Agama Islam. Peningkatan aktivitas belajar peserta didik dilakukan melalui penerapan Pembelajaran Kooperatif Tipe Jigsaw.Jenis penelitian yang dilakukan adalah penelitian tindakan kelas yang dilaksanakan dalam dua siklus. Masing-masing siklus terdiri dari empat pertemuan, dengan rincian sebagai berikut; pertemuan pertama, kedua dan ketiga adalah proses pembelajaran (tindakan) sedangkan pertemuan keempat tes akhir (evaluasi hasil belajar). Berdasarkan analisis data diketahui bahwa adanya peningkatan aktivitas belajar dan hasil belajar peserta didik. Dari data tes akhir siklus I diperoleh nilai rata-rata peserta didik kelas IXA 75,5 dan pada siklus II diperoleh nilai rata-rata 76,5 ini berarti terjadi peningkatan hasil belajar apabila dibandingkan dengan pembelajaran tanpa menggunakan model pembelajaran tipe Jigsaw. Berdasarkan hasil yang diperoleh dapat disimpulkan bahwa proses pembelajaran melalui pembelajaran kooperatif Tipe Jigsaw dapat meningkatkan aktivitas dan hasil belajar peserta didik IXA SMPN 2 Palupuh.
\end{abstract}

Keyword: Aktivitas, hasil belajar, pembelajaran kooperatif tipe jigsaw.

\section{PENDAHULUAN}

Masalah utama di bidang pendidikan pada saat ini adalah rendahnya mutu pendidikan pada berbagai jenjang. Khususnya Pendidikan Dasar dan Menengah yang ditandai dengan rendahnyanilai Ujian Sekolah (US). Berbagai usaha telah dilakukan pemerintah untuk meningkatkan mutu pendidikan, diantaranya penyempurnaan kurikulum, 
penambahan sarana dan prasarana pendidikan, peningkatan kualitas guru melalui pelatihan-pelatihan, peningkatan kualifikasi akademik guru, peningkatan kesejahteraan guru melalui pemberian tunjangan sertifikasi, workshop, musyawarah guru mata pelajaran (MGMP), dan lain-lainnya. Walaupun berbagai usaha telah dilakukan pemerintah namun belum menampakkan hasil yang signifikan.

Peserta didik dikatakan berhasil secara individu apabila ia telah mencapai ketuntasan belajar minimal untuk setiap indikator atau tujuan pembelajaran. Ketuntasan belajar dalam Kurikulum Tingkat Satuan Pendidikan (kurikulum 2006) adalah tingkat ketercapaian kompetensi ketuntasan belajar setelah peserta didik mengikuti kegiatan pembelajaran, yang dikenal dengan Kriteria Ketuntasan Minimal (KKM).KKM ideal adalah 75\%, artinya minimal $75 \%$ dari tujuan pembelajaran yang dirumuskan dalam perencanaan pembelajaran tercapai oleh peserta didik. Apabila kurang dari $75 \%$ pencapaian KKM oleh seorang peserta didik, maka dikatakan peserta didik tersebut belum tuntas dan yang bersangkutan harus mengikuti program perbaikan (remedial). Namun demikian sesuai dengan situasi dan kondisi, sekolah boleh saja menetapkan KKM-nya dibawah atau diatas KKM ideal.Sebagai contohKKM mata pelajaran Pendidikan Agama Islam (PAI) diSMPN 2 Palupuhtahun pelajaran 2016/2017 adalah 72 (tujuh puluh dua).

Fakta dilapangan justru menunjukkan hal yang jauh dari kondisi ideal, karena untuk mencapai KKM tujuh puluh lima (75) pada mata pelajaran Pendidikan Agama Islamdi SMPN 2 Palupuh agak sulit. Setelah dianalisis ternyata penyebabnya lebih banyak pada kurangnya aktivitas dan motivasi peserta didik mengikuti proses pembelajaran.Peneliti melihat sampai saat ini bahwa mata pelajaranPendidikan Agama Islam (PAI) masih menjadi mata pelajaran yang kurang disenangi oleh sebagian besar peserta didik.Kebanyakan peserta didik secara jujur mengungkapkan pelajaran PAI kurang menarik. Berdasarkan jawaban mereka, hal yang kurang menarik itu karena proses pembelajaran monoton. Pembelajaran yang dilakukan dimana guru menjelaskan materi dan siswa mendengarkan, kemudian mencatat materi tersebut.Peserta didikjuga kurang aktif mengajukan pertanyaan atau menjawab pertanyaan yang diajukan guru maupun mengomentari jawaban peserta didiklain yang kurang benar.

Kurangnya aktivitas dan motivasipeserta didik selama proses pembelajaran berlangsung berdampak pada rendahnya hasil belajar Pendidikan Agama Islam. Sebagai contoh nilai rata-rata ulangan harian ke-1 peserta didik

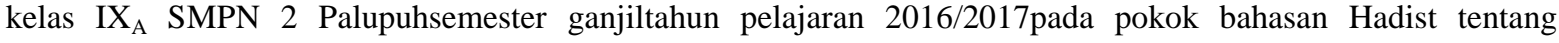
Menuntut Ilmuadalah 67,5 (enam tujuh koma lima). Hasil ini jauh dibawah kriteria ketuntasan minimal. Jumlah peserta didik yang tuntas 14 orang $(70,0 \%)$ dan yang belum tuntas 6 orang $(30,0 \%)$ dari 20 orang peserta didik.Apabila kondisi seperti ini dibiarkan terus tentu akan berdampak lebih buruk lagi terhadap hasil belajar peserta didik, oleh karena itu aktivitas dan motivasi peserta didik harus ditingkatkan. Untuk meningkatkan aktivitas, motivasi dan hasil belajar peserta didik maka guru harus dapat merancang pembelajaran dengan menggunakan model pembelajaran yang tepat. Menurut Sardiman (1996:95) aktivitas belajar adalah suatu perilaku yang selalu berusaha, bekerja atau belajar dengan sungguh-sungguh untuk mendapat kemajuan atau prestasi yang gemilang dari perubahan tingkah laku yang diperoleh dari pengalaman dan latihan. Faktor keberhasilan peserta didik dalam belajar sangat tergantung kepada keaktifan peserta didik itu sendiri sebagai subjek belajar. Menurut Lufri, dkk (2006:33) pembelajaran yang berbasis aktivitas akan menuntut kreativitas berfikir banyak. Apabila kita analisa pendapat Lufri, dkk maka untuk menciptakan aktivitas belajar peserta didik, guru harus memiliki pemikiran yang kreatif, sebab pembelajaran yang dituntut adalah peserta didik melakukan sesuatu (berbuat). Piaget dalam Sardiman (2001: 98) menjelaskan:" Bahwa anak itu berfikir sepanjang dia berbuat". Artinya, tanpa berbuat peserta didik itu tidak berfikir. Oleh karena itu agar peserta didik berfikir ia harus diberi kesempatan untuk berbuat/melakukan sesuatu.

Model pembelajaran yang dapat digunakan harus disesuaikan dengan ciri khas materi yang dipelajari. Jenis model pembelajaran seperti model pembelajaran kontekstual (contextualteaching and learning-CTL), model pembelajaran kooperatif (cooperative learning), model pembelajaran berbasis masalah (problem based learning), dan lainnya. Pada penelitian ini peneliti menerapkan model Pembelajaran KooperatifTipe Jigsaw.

Pembelajaran Kooperatif Type Jigsawmerupakan model pembelajaran dengan menggunakan sistem pengelompokan atau tim kecil, yaitu antara 4-6 orang yang mempunyai latar belakang kemampuan akademik, jenis kelamin, ras atau suku yang berbeda (heterogen)(Johnson \& Johnson, 1991). Sistem penilaian dilakukan terhadap kelompok. Setiap kelompok akan memperoleh penghargaan jika kelompok tersebut mampu menunjukkan prestasi yang dipersyaratkan. Dengan demikian, setiap anggota kelompok akan mempunyai 
ketergantungan positif terhadap kelompoknya, sehingga setiap individu akan saling membantu untuk keberhasilan kelompoknya.

Proses pembelajaran melalui penerapan model pembelajaran kooperatif tipe Jigsawdiharapkan dapat meningkatkan aktivitas dan motivasibelajar peserta didik sehingga berdampak positif terhadap hasil belajar Pendidikan Agama Islam. Berdasarkan uraian diatas, maka dilakukan penelitianmodel pembelajaran kooperatif dengan tipe jigsaw. Penelitian ini diberi judul "Peningkatan Aktivitas dan Hasil Belajar Peserta DidikKelas IXA SMPN 2 Palupuh Pada Mata PelajaranPendidikan Agama IslamMelalui Pembelajaran KooperatifTipe Jigsaw".Berdasarkan latar belakang permasalahan, maka rumusan masalahadalah Bagaimanakah penerapan Pembelajaran Kooperatif Tipe Jigsawdapat meningkatkan aktivitas dan hasil belajar Pendidikan Agama Islampeserta didikkelas IXA SMPN 2 Palupuh?”.

\section{METODE}

Penelitian ini menggunakan metode Penelitian Tindakan Kelas (PTK) yang dikembangkan oleh Kemmis dan

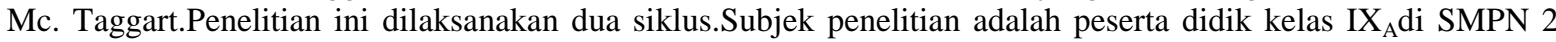
Palupuh, Kabupaten Agam berjumlah 20 orangyang terdiri atas 8 orang pria dan 12 orang wanita. Penelitian ini dilaksanakan padasemester ganjiltahun pelajaran 2016/2017. Sekolah ini di sebelah timurberbatasan dengan jalan raya Bukittingi-Medan, di sebelah barat berbatasan dengan jalan Nagari Nan Tujuah, di sebelah selatan dan utara berbatasan dengan rumah penduduk.

Setiap siklus PTK ini terdiri atas perencanaan (planning), tindakan (action), observasi (observation) dan refleksi (reflection).Langkah-langkah yang dilakukan dalam setiap siklus sebagai berikut.

\section{Tahap Perencanaan}

1. Mengidentifikasi konsep PAI yang akan diajarkan, yaitu konsep-konseppenting tentang materi Iman kepada Hari Akhir.

2. Mempersiapkan RPP, lembar ahli dan alat evaluasi hasil belajar.

3. Menentukan urutan dan strategi pembelajaran untuk memaksimalkan keterlibatan peserta didik.

4. Membagi peserta didik menjadi 4 kelompok asal secara heterogen.

5. Mendesain tabel pengamatan aktivitas, angket umpan balikdan daftar nilai.

6. Mempersiapkan daftar hadir peserta didik.

\section{Tahap tindakan (action)}

Tahap tindakan dilaksanakan dalam empat pertemuan, yaitu pertemuan pertama, kedua dan ketiga adalah proses pembelajaran dengan menerapkanmodel pembelajaran kooperatiftipe Jigsawsedangkan pertemuan keempat untuk tes akhir. Adapun langkah-langkah yang dilakukan pada setiap pertemuan adalah sebagai berikut: 1. Pendahuluan (10 menit)

a. Mengecek kehadiran peserta didik.

b. Memotivasi peserta didik dengan pertanyaan yang dapat menimbulkan rasaingintahu peserta didik terhadap pelajaran yang akan dipelajari.

c. Memberikan apersepsi, yaitu mengaitkan materi pelajaran denganpelajaran sebelumnya.

d. Menuliskan topik pelajaran di papan tulis dan membacakan tujuan pelajaran yang ingin dicapai.

2. Kegiatan inti (55 menit)
a. Guru membagi peserta didik atas 5 kelompok asal, masing-masing kelompok terdiri atas 4 orang. Semua anggota kelompok asal heterogen.
b. Guru meminta peserta didikduduk menurut kelompok asal yang telahditentukan.
c. Guru menentukan anggota tim ahli dan menyampaikan topik/materi yang harus dibahas/dipelajari(pemberian tugas).
d. Guru meminta peserta didik yang mendapat tugas membahas materi yang sama agar dapat membentuk kelompok ahli dan mendiskusikannya dalam kelompok (diskusi kelompok ahli).
e. Guru meminta setiap anggota kelompok ahli dari kelompok asal untuk kembali ke kelompok asalnya untuk menjelaskan materi yang dibahas dan didiskusikan pada kelompok asal (diskusi kelompok asal)
f. Guru memintasetiap tim ahli untukmempersentasikan hasil kerja di depan kelas. 
g. Peserta didik lain diminta untuk bertanya dan atau menanggapinya

h. Guru mengkonfirmasikanmateri yang masih kurang dipahami pesertadidik dan memberikan penekanan pada materi penting.

i. Guru meminta peserta didik untuk memberikan tepuk tangan pada kelompokpresentasi dan guru meyampaikan ucapan terima kasih dan penghargaan pada kelompok dan atau peserta didik yang paling menonjol (aktif).

3. Penutup (15 menit)

a. Guru bersama peserta didik menyimpulkan materi pelajaran.

b. Guru memberikan tes daya serap (kuis).

\section{Tahap Observasi (observation)}

Selama pembelajaran berlangsung observer mengamati dan mencatat aktivitas positif dalam lembaran observasi dan aktifitas negatif pada bagian catatan lapangan.Observer juga diminta untuk mengamati kesan umum pembelajarandari tampilan guru.Setelah selesai observasi, penelitiberdiskusi dengan observer untuk melihat:

1. Peserta didik yang mencapai hasil belajar tinggi, sedang danrendah.Jawabannyaakan memberi petunjuk secara umum tentang keberhasilan pembelajaran.

2. Karakteristik Peserta didik yang menunjukkan pencapaian hasil belajar tinggi, sedang dan rendah. Jawabannya akan memberi petunjuk bagi upaya memahami kemampuan peserta didik.

3. Penyebab peserta didik tersebut mencapai hasil belajar rendah. Jawabannyaakan memberi petunjuk pada diagnosis kesulitan belajar.

4. Aspek yang masih kurang dari proses pembelajaran. Jawabannya akan memberi petunjuk tentang upaya perbaikan/revisi perencanaan pembelajaran (RPP) dan tindakan pada siklus II.

\section{Tahap refleksi (reflection)}

Peneliti menganalisis data-data dari observasi, angket umpan balik peserta didik dan hasil belajarnya untuk melihat keunggulan dan kelemahan pelaksanaan siklus I. Agar dapat diperbaiki pada siklus berikutnya.

\section{HASIL DAN PEMBAHASAN}

\section{Hasil Penelitian}

\section{Siklus I}

Pengamatan terhadap aktivitas peserta didiksetiap pertemuan dilakukan selama proses pembelajaranberlangsung.Pertemuan pertama dengan topik "Pengertian iman kepada hari akhirserta dalil naqli dan dalil aqlinya".Pertemuan ke-2 dengan topik"Kehidupan akhirat dan kehidupan dunia hanya sementara"dan pertemuan ke-3 dilaksanakan dengan topik "Fungsi iman kepada hari akhir".Pelaksanaan pembelajaran untuk tiga kali pertemuan ini sesuai dengan langkah-langkah yang disampaikan pada metodologi penelitian.

Aktivitas-aktivitas belajar yang dilakukan peserta didik selama proses pembelajaran pada siklus Iini yaitu membaca/membuat lembar ahli, keterlibatan berdiskusi dengan temannya, bertanya, menjawab pertanyaan, menanggapi jawaban pertanyaan, dan mencatat kesimpulan materi pelajaran diamati secara serius oleh pengamat.Adapun hasil pengamatan aktivitas-aktivitasdapat dilihat pada tabel berikut ini:

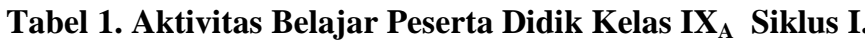

\begin{tabular}{|c|c|c|c|c|c|c|c|c|}
\hline \multirow[t]{2}{*}{ No } & \multirow[t]{2}{*}{ Aktivitas Peserta Didik } & \multicolumn{6}{|c|}{$\begin{array}{c}\text { Jumlah dan Persentase Peserta Didik yang } \\
\text { Beraktivitas Pertemuan ke- }\end{array}$} & \multirow[t]{2}{*}{$\begin{array}{l}\text { Rata- } \\
\text { Rata }\end{array}$} \\
\hline & & 1 & $\%$ & 2 & $\%$ & 3 & $\%$ & \\
\hline 1 & Terlibat diskusi & 14 & 70,0 & 15 & 75,0 & 18 & 90,0 & 78,3 \\
\hline 2 & Membaca/membuat lembar ahli & 15 & 75,0 & 17 & 85,0 & 18 & 90,0 & 83,3 \\
\hline 3 & Bertanya & 4 & 20,0 & 4 & 20,0 & 6 & 30,0 & 25,0 \\
\hline
\end{tabular}




\begin{tabular}{lllllllll}
\hline 4 & Menjawab & 4 & 20,0 & 4 & 20,0 & 6 & 30,0 & 25,0 \\
5 & Menanggapi & 3 & 15,0 & 4 & 20,0 & 6 & 30,0 & 21,7 \\
$\mathbf{6}$ & Mencatat kesimpulanmateri & 17 & 85,0 & 19 & 90,0 & 19 & 95,0 & 90,0 \\
& Rata-rata keaktifan peserta didik & & 50,8 & & 51,7 & & 60,8 & \\
\hline
\end{tabular}

Dari tabel di atas terlihat aktivitas peserta didik selama pembelajaran pada siklus I. Pada tabel tersebut terlihat perkembangan aktivitas peserta didik dari setiap pertemuan.Aktivitas yang terdapat peningkatan adalah aktivitas peserta didik yang terlibat dalam diskusi, membaca/membuat lembar ahli, menanggapi dan mencatat kesimpulan materi pelajaran. Sedangkan aktivitas bertanya dan menjawab pertanyaan dari pertemuan 1 ke pertemuan 2 tetap, tetapi dari pertemuan 2 ke pertemuan 3 meningkat. Untuk lebih mudah memahami perkembangan aktivitas peserta didik maka dapat dilihat pada grafik berikut ini:

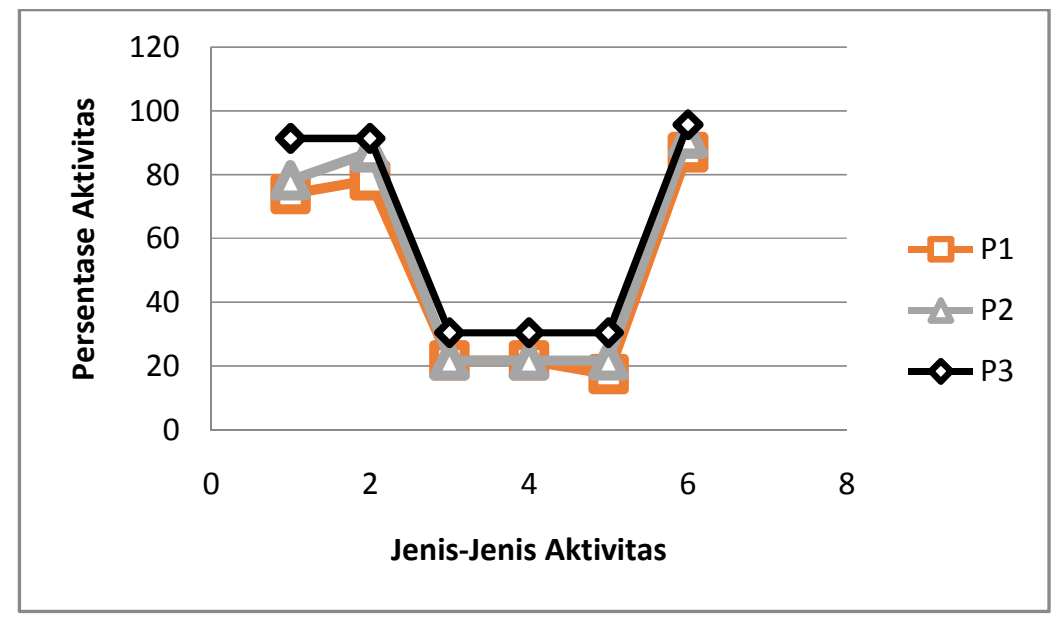

\section{Gambar 1. GrafikAktivitas Peserta Didik Siklus I}

Berdasarkan gambar 1 terlihat kecendrungan aktivitas positif peserta didik mengalami peningkatan mulai dari pertemuan 1,2 dan 3.

Umpan balik dari peserta didik mengenai pemahamannya terhadap konsep-konsep penting, kesimpulan materi pelajaran, dan kesenangan pada cara belajar yang diterapkan diberikan angketpada pertemuan keempat,setelah selesai melaksanakan tes akhir diminta peserta didik untuk menjawabnya. Hasil umpan balik dari peserta didik adalah sebagai berikut:

Tabel 2. Hasil Umpan Balik Peserta Didik Kelas IX

\begin{tabular}{|c|c|c|c|c|c|c|c|c|c|c|c|}
\hline \multirow[t]{2}{*}{ No } & \multirow[t]{2}{*}{ Umpan balik } & \multicolumn{2}{|c|}{$\begin{array}{l}\text { Sangat } \\
\text { Kurang }\end{array}$} & \multicolumn{2}{|c|}{ Kurang } & \multicolumn{2}{|c|}{ Sedang } & \multicolumn{2}{|l|}{ Baik } & \multicolumn{2}{|c|}{ Sangat Baik } \\
\hline & & $\begin{array}{r}\text { Jml } \\
\text { (org) }\end{array}$ & $\%$ & $\begin{array}{r}\text { Jml } \\
\text { (org) }\end{array}$ & $\%$ & $\begin{array}{c}\text { Jml } \\
\text { (org) }\end{array}$ & $\%$ & $\begin{array}{l}\text { Jml } \\
\text { (org) }\end{array}$ & $\%$ & $\begin{array}{l}\text { Jml } \\
\text { (org) }\end{array}$ & $\%$ \\
\hline 1 & $\begin{array}{l}\text { Memahami konsep- } \\
\text { konsep penting }\end{array}$ & - & - & - & - & 5 & 25,0 & 11 & 55,0 & 4 & 20,0 \\
\hline 2 & $\begin{array}{l}\text { Memahami kesimpulan } \\
\text { materi }\end{array}$ & - & - & - & - & 4 & 20,0 & 12 & 60,0 & 4 & 20,0 \\
\hline
\end{tabular}




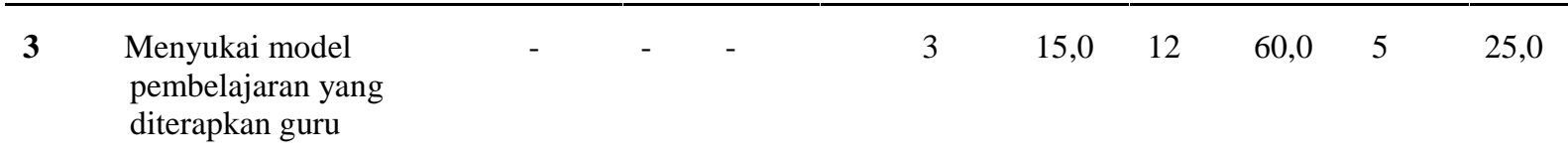

Tabel2menunjukkan bahwa jumlah peserta didik yang memahami konsep-konsep penting materi pelajaran kategori sangat kurang dan kurang tidak ada (0\%), kategori sedang 5 orang (25\%), kategori baik 11 orang $(55 \%)$ dan kategori sangat baik 4 orang $(20 \%)$. Apabila dijumlahkan persentase kategori baik dan sangat baik maka jumlahnya ada 15 orang(75\%).Hal ini dapat disimpulkan bahwa secara umum peserta didik memahami konsepkonsep penting materi pelajaran.

Selanjutnya jumlah peserta didik yang memahami kesimpulan materi pembelajaran kategori sangat kurang dan kurang tidak ada (0\%). Kategori sedang 4 orang (20\%), kategori baik 12 orang (60\%) dan kategori sangat baik 4orang (20\%). Apabila dijumlahkan persentase kategori baik dan sangat baik maka jumlahnya 16 orang $(80 \%)$.Hal ini berarti secara umum peserta didik memahami kesimpulan materi.

Peserta didik yang menyukai model pembelajaran yang diterapkan guruberada pada kategori sangat kurang dan kurang tidak ada (0\%), kategori sedang ada sebanyak 3 orang (15\%), kategori baik ada sebanyak 12 orang $(60 \%)$ dan kategori sangat baik ada sebanyak 5 orang $(25 \%)$.Apabila dijumlahkan persentase kategori sedang, baik dan sangat baik maka ada sebanyak 17 orang (85\%).Hal ini dapat disimpulkan bahwa secara umum peserta didik menyukai model pembelajaran yang diterapkan guru.

Agarlebih mudah memahami dan mengambil kesimpulan secara lebih rinci bagaimana umpan balik peserta didik tentang pemahamannya terhadap konsep-konsep penting, kesimpulan materi pelajaran dan kesukaannya terhadap model pembelajaran yang diterapkan guru pada siklus I maka dapat dilihat pada gambar-gambar berikut:

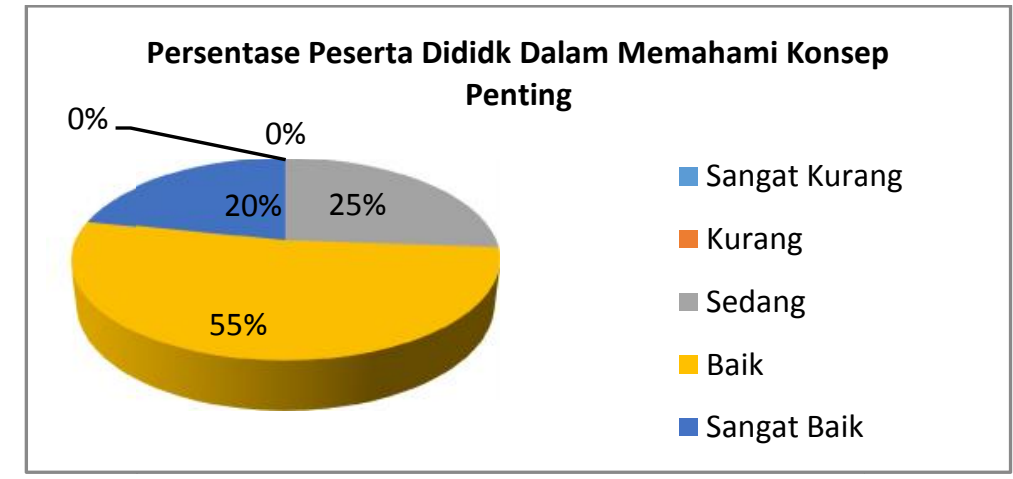

Gambar 2 Umpan balik peserta didikterhadap konsep-konsep penting

Pada gambar 2 terlihat peserta didik yang tergolong memahami konsep-konsep penting materi kategori sangat kurang dan kurang tidak ada (0\%), kategori sedang 25\%, kategori baik 55\% dan kategori sangat baik $20 \%$.

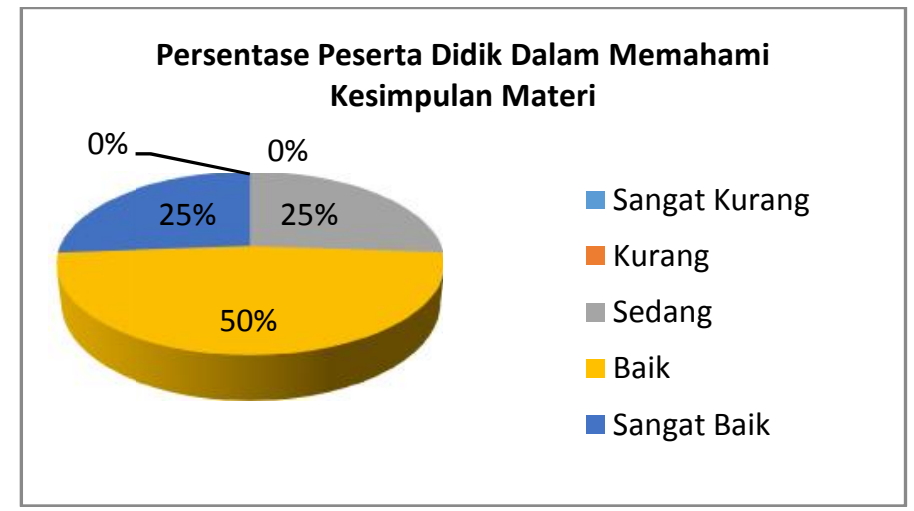




\section{Gambar 3.Umpan Balik Peserta Didik terhadap Pemahaman Konsep}

Pada gambar 3, terlihat peserta didik yang dapatmemahami kesimpulan materi pelajaran dengan kategori sangat kurang dan kurang tidak ada (0\%), kategori sedang 25\%, kategori baik 50\% dan kategori sangat baik $25 \%$.

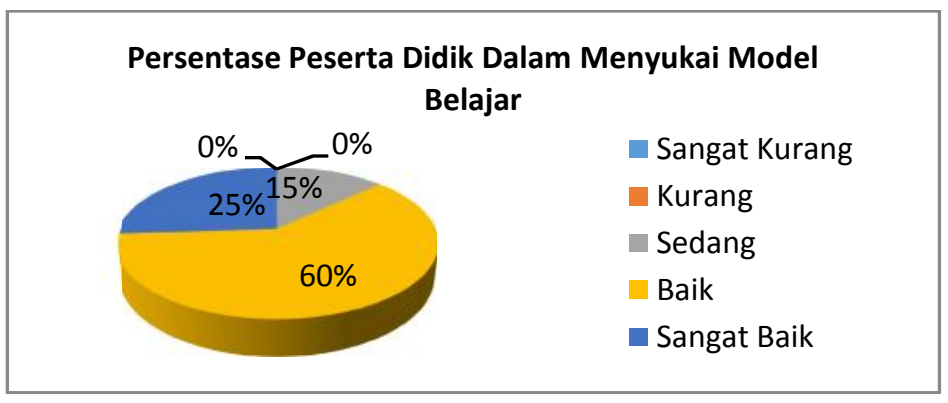

\section{Gambar 4.Peserta Didik Menyukai Model Belajar}

Pada gambar 4, terlihat peserta didik yang menyukai model belajar yang diterapkan guru kategori sangat kurang dan kurang tidak ada (0\%), kategori sedang sebesar 15\%, kategori baik sebesar $60 \%$ dan kategori sangat baik sebesar $25 \%$.

Kuis atau tes daya serap dilakukan pada akhir proses pembelajaran untuk setiap pertemuan. Bentuk soal kuis adalah pilihan ganda. Pemberian kuis kepada peserta didik untuk mengetahui seberapa besar tujuan pembelajaran yang dirumuskan pada RPP tercapai.Tes akhirsiklus I dilaksanakan dengan menggunakansoalpilihan ganda dengan jumlah 20 pertanyaan.Waktu mengerjakan soal ini selama 50 menit.Gambaran umum hasil kuis dan tes akhir siklus I sebagai berikut:

Tabel 3. Nilai Kuis dan Tes Akhir Siklus I

\begin{tabular}{cccccc}
\hline No & Nilai & Pertemuan 1 & Pertemuan 2 & Pertemuan 3 & Tes Akhir \\
\hline $\mathbf{1}$ & Nilai tertinggi & 100 & 100 & 100 & 100 \\
$\mathbf{2}$ & Nilai terendah & 45 & 50 & 60 & 50 \\
$\mathbf{3}$ & Nilai Rata-rata & 71,5 & 74,5 & 76,0 & 75,5 \\
\hline
\end{tabular}

Jumlah peserta didik yang mencapai KKM (tuntas) 16 orang $(80 \%)$ dan yang belum tuntas 4 orang (20\%).Jumlah peserta didik yang mencapai kriteria ketuntasan minimal (KKM) sudah mencapai $80 \%$, ini berarti indikator keberhasilan tindakan pada siklus I sudah tercapai.

Catatan lapangan selama porses pembelajaran berlangsung ditemukan beberapa aktivitas negatif peserta didik dan beberapa kendala yang perlu diperhatikan untuk perbaikan pada siklus II.Aktivitas-aktivitas negatif yang ditemukan pada siklus I adalah berbicara dengan teman, mengerjakan tugas lain, melihat handpone (HP), minta izin keluar dan menyontek saat kuis/ulangan. Adapun hasil rekapitulasi aktivitas negatif peserta didik dapat dilihat pada tabel berikut ini:

Tabel 4. Aktivitas Negatif Peserta Didik Pada Siklus I

\begin{tabular}{llccc}
\hline No & Aktivitas Negatif & \multicolumn{2}{c}{ Pertemuan ke- } \\
\cline { 3 - 5 } & & 1 (org) & $2($ org) & $3($ org) \\
$1 \quad$ Berbicara dengan teman & 4 & 2 & 2 \\
\hline
\end{tabular}




\begin{tabular}{|c|c|c|c|c|}
\hline 2 & Mengerjakan tugas lain & 2 & 1 & - \\
\hline 3 & Melihat HP & 2 & 1 & - \\
\hline 4 & Minta izin keluar & 3 & 2 & 1 \\
\hline 5 & Menyontek ketika kuis/ulangan & 4 & 2 & 2 \\
\hline
\end{tabular}

Tabel 4terlihat bahwa aktivitas negatif yang selalu mengalami penurunan adalah mengerjakan tugas lain, melihat HP dan minta izin keluar. Sedangkan aktivitas berbicara dengan teman dan menyontek ketika kuis dari pertemuan 1 ke pertemuan 2 mengalami penurunan (ada perbaikan), tetapi dari pertemuan 2 ke pertemuan 3 tetap.

Kemudian selain dari beberapa aktivitas negatif dari catatan lapangan juga ditemukan beberapa kendala yang terjadi pada siklus I yaitu:

1) Peserta didik yang berani tampil sebagai pembicara pada presentasi didepan kelas adalah peserta yang tergolong pintar dan orangnya cenderung tetap.

2) Alokasi waktu yang kurang pada pertemuan pertama.

3) Kurang beraninya peserta didik bertanya, menjawab maupun menanggapi jawaban peserta didik lain.

4) Masih ditemui peserta didik yang mentertawakan temannya yang bertanya atau menanggapi dan yang tampil sebagai pembicara pada saat persentasi.

Hasil observasi terhadap aktivitas belajar peserta didik, secara umum diketahui terjadi peningkatan aktivitas positif dan penurunan aktifitas negatif.Dari hasil analisis data, aktivitas belajar peserta didik yang masih tergolong rendah walaupun ada peningkatan adalah aktifitas bertanya, menjawab pertanyaan dan aktivitas menanggapi.Untuk itu pada siklus II harus ada upaya perbaikan agar terjadi peningkatan aktivitas yang masih rendah ini.Aktivitas belajar peserta didik yang sudah tergolong baik adalah aktivitas terlibat diskusi dengan teman, dan mencatat kesimpulan materi pelajaran, namun pencapaian aktivitas ini belum maksimal, oleh karena itu masih perlu ditingkatkan.

Aktivitas negatif yang sangat signifikan penurunannya adalah aktivitas mengerjakan tugas lain dan melihat HP, karena pada pertemuan ke-3 sudah tidak ada lagi aktivitas ini. Namun demikian aktivitas negatiflain seperti berbicara dengan teman, minta izin keluar dan menyontek pada saat kuis atau ulangan juga sudah menurun. Untuk itu pada siklus II masih perlu upaya agaraktivitas negatifterus menurun.

Rendahya aktivitas peserta didik dalam bertanya disebabkan oleh1)Peserta didik merasa malu dan takut salah dalam bertanya.2) Peserta didik kurang lancar bertanya dengan menggunakan bahasa yang baik.Rendahnya aktivitas peserta didik dalam menjawab pertanyaan ataupun menanggapinya disebabkan oleh1)Peserta didik takut salah dalam menjawab dan atau menanggapi karena bisa ditertawakan oleh teman-temannya.2)Peserta didik memang tidak tahu jawabannya atau memang tidak bisa menanggapinya.3)Peserta didik kurang berani menjawab atau menanggapinya.

Hasil belajar peserta didik dengan nilai rata-rata tes akhir 75,2(tujuh puluh lima koma dua).Hasil ini menunjukkan bahwa ketuntasan belajar secara klasikal sudah tercapai. Ketuntasan secara klasikal menurut penelitian ini adalah $75 \%$ (tujuh puluhlima persen) peserta didik yang dijadikan sampel telah mencapai KKMyang ditetapkan sekolah yaitu 72.Untuk menanggulangi masalah ini maka guru perlu mempertajam konsep-konsep penting materi pelajaran dan memotivasi peserta didik agar lebih memahami materi-materi dengan memperhatikan tujuan pembelajaran sebagai rambu-rambunya. berikut:

Selanjutnya dilihat dari catatan lapangan ditemukan beberapa kendala atau kelemahan pada siklus I sebagai

1) Kebanyakan peserta didik tidak mau tampil sebagai pembicara persentasi.Agar peserta didik mau tampil sebagai pembicara persentasi, maka guru sebaiknya mengadakan kesepakatan dengan peserta didik yaitu mengadakan undian/cabut lot. Siapa yang terpilih, maka dialah yang akan tampil sebagaipembicara pada kelompoknya masing-masing. 
2) Terjadi kekurangan waktu pada pertemuan pertama.Agar tidak terjadi lagi kekurangan waktu, maka guru perlu mengefektifkanwaktu pada saat kegiatan pendahuluan dan diskusi kelompok dengan meminta peserta didik membaca materi pelajaran tersebut terlebih dahulu di rumah.

3) Tidak semua peserta didik terlibat diskusi.Agar jumlah peserta didik terlibat diskusi kelompok meningkat maka guru perlumenyampaikan bahwa yang dinilai bukan hasil ujian saja tetapi juga keterlibatannyadalam diskusi.

4) Tidak semua peserta didik membaca/membuat lembar ahli.Agar peserta didik mau membaca/membuat lembarahli, maka guru perlu menekankan bahwakeberhasilan kelompok asal sangat bergantung padaanggota kelompok ahli.

5) Secara umum peserta didik tidak berani bertanya, menjawab pertanyaan dan menanggapinya.Agar peserta didik mau bertanya, menjawab pertanyaan ataupun menanggapi jawaban pertanyaan, maka guru perlu memberikan penguatan dan penghargaan.Penguatan dan penghargaan bisa dalam bentuk kata-kata atau isyarat sehingga timbul rasa percaya dirinya, karena merasa dihargai.

6) Masih ada peserta didik yang melakukan aktivitas negatif.Agar peserta didik tidak melakukan aktivitas negatif, seperti bercanda/ berbicara dengan teman, melihat HP, minta izin keluar kelas, menyontek ketika ujian/kuis maka guru perlu memberitahu peserta didik bahwa aktivitas negatifnya akan dicatat dan akan menjadi bahan pertimbangan untuk penilaian sikap.

\section{Siklus II}

Aktivitas belajar peserta didik yang diamati pada siklus II sama dengan siklus I, yaitu terlibat diskusi dengan teman, membaca/membuat lembar ahli, bertanya, menjawab pertanyaan, menanggapi jawaban pertanyaan dan mencatat kesimpulan materi pelajaran. Hasil pengamatan aktivitas belajar peserta didik pada siklus II dapat dilihat pada tabel berikut:

Tabel 5. Aktivitas Belajar Peserta Didik Kelas $\mathbf{I X}_{\mathrm{A}}$ Siklus II

\begin{tabular}{|c|c|c|c|c|c|c|c|c|}
\hline \multirow[t]{2}{*}{ No } & \multirow[t]{2}{*}{ Aktivitas Peserta Didik } & \multicolumn{6}{|c|}{$\begin{array}{c}\text { Jumlah dan Persentase Peserta Didik yang } \\
\text { Beraktivitas Pertemuan ke- }\end{array}$} & \multirow[t]{2}{*}{$\begin{array}{l}\text { Rata- } \\
\text { rata }\end{array}$} \\
\hline & & 1 & $\%$ & 2 & $\%$ & 3 & $\%$ & \\
\hline 1 & Terlibat diskusi & 15 & 75,0 & 17 & 85,0 & 18 & 90,0 & 83,3 \\
\hline 2 & Membaca/membuat lembar ahli & 17 & 85,0 & 19 & 95,0 & 20 & 100,0 & 93,3 \\
\hline 3 & Bertanya & 5 & 25,0 & 6 & 30,0 & 6 & 30,0 & 28,3 \\
\hline 4 & Menjawab & 5 & 25,0 & 6 & 30,0 & 6 & 30,0 & 28,3 \\
\hline 5 & Menanggapi & 5 & 25,0 & 5 & 25,0 & 6 & 30,0 & 26,7 \\
\hline 6 & Mencatat kesimpulanmateri & 18 & 90,0 & 19 & 95,0 & 20 & 100 & 95,0 \\
\hline & Rata-rata keaktifan peserta didik & & 54,2 & & 60,0 & & 63,3 & \\
\hline
\end{tabular}

Dari tabel terlihat bahwa aktivitas peserta didik yang selalu mengalami peningkatan pada siklus II adalah terlibat diskusi dengan teman, membaca/membuat lembar ahli, menanggapi dan mencatat kesimpulan materi pelajaran.Sedangkan aktivitas bertanya dan menjawab dari pertemuan 1 ke pertemuan 2 meningkat tetapi dari pertemuan 2 ke pertemuan 3 tetap.Untuk lebih mudah memahami data tabel 5,perhatikan gambargrafik berikut ini: 


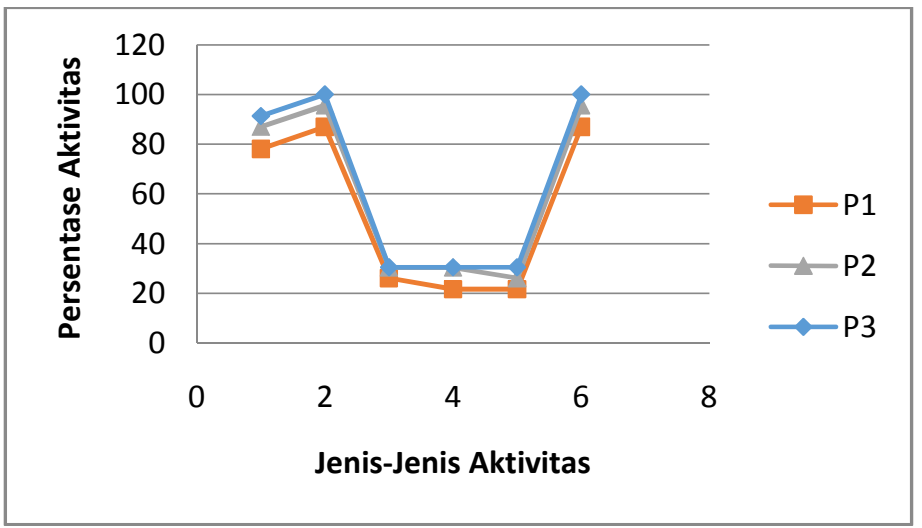

Gambar 5. Grafik Akitivitas Peserta Didik Siklus II

Umpan balik dari peserta didik mengenai pemahamannya pada konsep-konsep penting, kesimpulan materi pelajaran, dan kesukaannya pada cara belajar diberikan angket pada pertemuan keempat setelah selesai melaksanakan tes akhir/evaluasi belajar siklus II. Hasil umpan balik dari peserta didik siklus II adalah sebagai berikut:

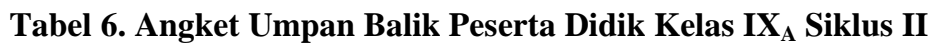

\begin{tabular}{|c|c|c|c|c|c|c|c|c|c|c|c|}
\hline \multirow[t]{2}{*}{ No } & \multirow[t]{2}{*}{ Umpan balik } & \multicolumn{2}{|c|}{$\begin{array}{l}\text { Sangat } \\
\text { Kurang }\end{array}$} & \multicolumn{2}{|c|}{ Kurang } & \multicolumn{2}{|c|}{ Sedang } & \multicolumn{2}{|c|}{ Baik } & \multicolumn{2}{|c|}{ Sangat Baik } \\
\hline & & $\begin{array}{l}\text { Jml } \\
\text { (or) }\end{array}$ & $\%$ & $\begin{array}{l}\text { Jml } \\
\text { (or) }\end{array}$ & $\%$ & $\begin{array}{l}\text { Jml } \\
\text { (or) }\end{array}$ & $\%$ & $\begin{array}{l}\text { Jml } \\
\text { (or) }\end{array}$ & $\%$ & $\begin{array}{l}\text { Jml } \\
\text { (or) }\end{array}$ & $\%$ \\
\hline 1 & $\begin{array}{l}\text { Memahami konsep- konsep } \\
\text { penting }\end{array}$ & - & - & - & - & 4 & 20,0 & 11 & 55,0 & 5 & 25,0 \\
\hline 2 & $\begin{array}{l}\text { Memahami kesimpulan } \\
\text { materi }\end{array}$ & - & - & - & - & 4 & 20,0 & 11 & 55,0 & 5 & 25,0 \\
\hline 3 & $\begin{array}{l}\text { Menyukai model } \\
\text { pembelajaran yang } \\
\text { diterapkan guru }\end{array}$ & - & - & - & - & 2 & 10,0 & 13 & 65,0 & 5 & 25,0 \\
\hline
\end{tabular}

Dari tabel6, terlihat bahwa jumlah peserta didik yang memahami konsep-konsep penting kategori sangat kurang dan kurang tidak ada (0\%), kategori sedang sebanyak4 orang (20\%), kategori baik sebanyak 11 orang $(55 \%)$ dan kategori sangat baik sebanyak 5 orang (25\%). Jumlah dari kategori baik dan sangat baik 16 orang (80\%).Daridata ini disimpulkan bahwa secara umum peserta didik memahami konsep-konseppenting.Peserta didik yang memahami kesimpulan materi kategori sangat kurang dan kurang tidak ada (0\%), kategori sedangsebanyak 4 orang (20\%), kategori baik sebanyak11orang (55\%) dan kategori sangat baik sebanyak5 orang (25\%). Jumlah dari kategori baik dan sangat baik sebanyak16 orang (80\%). Dari hasil analisisini disimpulkan bahwa secara umum peserta didik memahami kesimpulan materi pelajaran. Selanjutnya jumlah peserta didik yang menyukai model belajar yang diterapkan guru kategori sangat kurang dan kurang tidak ada (0\%), kategori sedang sebanyak2 orang (10\%), kategori baik sebanyak13 orang (65\%) dan kategori sangat baik sebanyak5 orang (25\%). Jumlah dari kategori baik dan sangat baik sebanyak18 orang (90\%). Dari hasil ini disimpulkan bahwa secara umum peserta didik menyukai model belajar yang diterapkan. 
Kemudian agarlebih mudahmelihat bagaimana umpanbalikpesertadidiktentangpemahamannya padakonsep penting, kesimpulan materi, dan kesukaannya pada model belajar yang diterapkanguru pada siklus IIperhatikan gambar berikut:

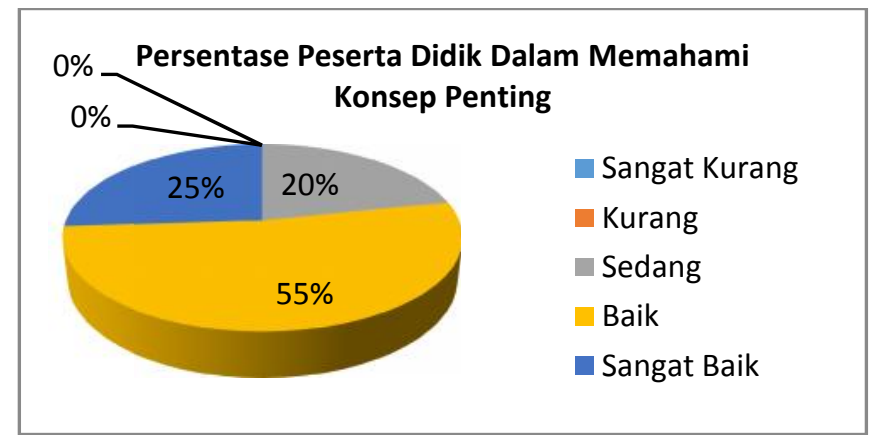

\section{Gambar 6.Pemahaman Peserta Didik Pada Konsep-Konsep Penting}

Pada gambar 6 terlihat peserta didik yang tergolong memahami konsep-konsep pentingkategori sangat kurang dan kurang (0\%), kategori sedang sebanyak 20\%, kategori baik sebanyak55\% dan sangat baiksebanyak $25 \%$.Peserta didik yang tergolong kategori sangat kurang, kurang dan sedang disimpulkan sebagaipeserta didik yang belummemahami konsep penting.

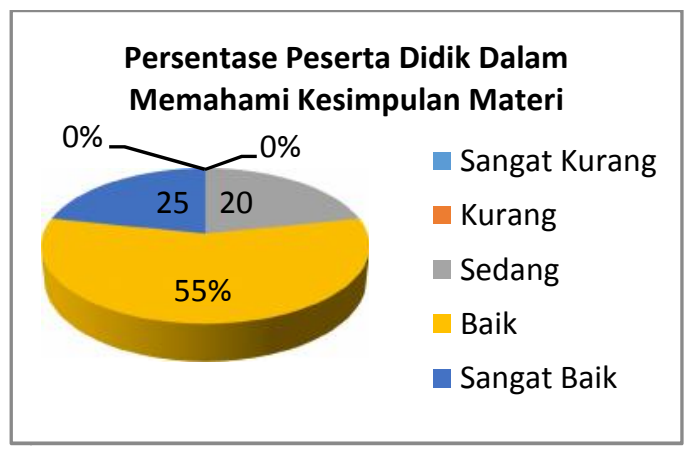

\section{Gambar 7.Peserta DidikMemahami Kesimpulan Materi Pelajaran}

Pada gambar 7, terlihat peserta didik yang tergolong memahami kesimpulan materi pelajarankategori sangat kurang dan kurang $0 \%$, sedang sebesar 20\%, baiksebesar55\% dan sangat baiksebesar25\%.Peserta didik yang tergolong kategori sangat kurang, kurang dan sedang disimpulkan sebagai peserta didikyangbelummemahami kesimpulan materipelajaran.

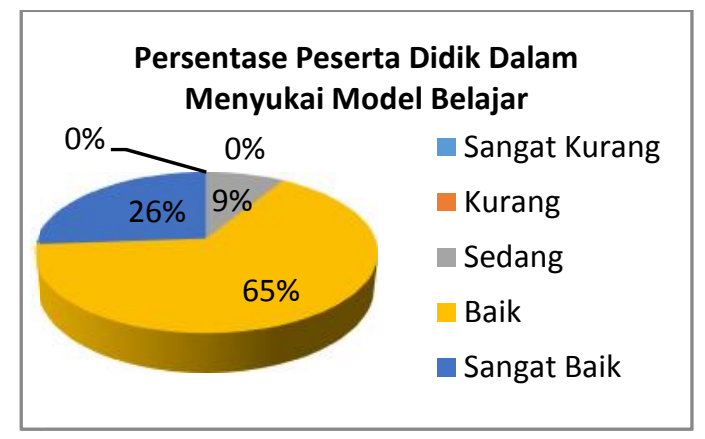

Gambar 8.Peserta Didik Menyukai Model Belajar 
Pada gambar 8. terlihat peserta didik yang tergolong menyukai model pembelajaran yang digunakan kategori sangat kurang $0 \%$, kategori kurang $0 \%$, kategori sedang 10\%, kategori baik $65 \%$ dan sangat baik $25 \%$.

Kuis/tes daya serap dan tes akhir pada siklus II dilakukan padaakhir proses pembelajaran setiap kali pertemuan, sama dengan siklus I. Bentuk soal kuis adalah pilihan ganda dengan jumlah 20 soal dan waktu pelaksanaannya 50 menit. Adapun hasil kuis dan tes akhir siklus II dapat dilihat pada tabel berikut ini.

Tabel 7. Nilai Kuis dan Tes Ahkir Siklus II

\begin{tabular}{crcccc}
\hline No & Nilai & Pertemuan 1 & Pertemuan 2 & Pertemuan 3 & Tes Akhir \\
\hline $\mathbf{1}$ & Nilai tertinggi & 100 & 100 & 100 & 100 \\
$\mathbf{2}$ & Nilai terendah & 50 & 50 & 60 & 55 \\
$\mathbf{3}$ & Nilai Rata-rata & 75,5 & 76,0 & 77,5 & 76,5 \\
\hline
\end{tabular}

Berdasarkan tabel 7 diketahui bahwa jumlah peserta didik yang mencapai ketuntasan ada 17 orang $(85 \%)$ dan yang belum tuntas sebanyak 3 orang (15\%).Jumlah peserta didik yang mencapai kriteria ketuntasan minimal (KKM) lebih dari $75 \%$, ini berarti indikator keberhasilan tindakan pada siklus II tercapai/terpenuhi.

Catatan lapangan selama porses pembelajaran berlangsung pada siklus II ditemukan aktivitas-aktivitas negatif yang seperti berbicara dengan teman, mengerjakan tugas lain, melihat hand pone (HP), minta izin keluar dan menyontek saat kuis/ulangan. Adapun hasil rekapitulasi aktivitas negatif peserta didik sebagai berikut:

Tabel 8. Aktivitas Negatif Peserta Didik Siklus II

\begin{tabular}{llccc}
\hline No & \multicolumn{1}{c}{ Aktivitas Negatif } & \multicolumn{2}{c}{ Pertemuan ke- } \\
\cline { 3 - 5 } & & 1 (org) & 2 (org) & $3($ org) \\
$\mathbf{1}$ & Berbicara dengan temannya & 3 & 2 & - \\
$\mathbf{2}$ & Mengerjakan tugas lain & 2 & 1 & - \\
$\mathbf{3}$ & Melihat HP & 2 & - & - \\
$\mathbf{4}$ & Minta izin keluar & 2 & 1 & 2 \\
$\mathbf{5}$ & Menyontek ketika kuis/ulangan & 3 & 3 & \\
\hline
\end{tabular}

Tabel8 memperlihatkan bahwa aktivitas negatif peserta didik yang terus mengalami penurunan adalah berbicara dengan teman lain, mengerjakan tugas lain, melihat HP, dan minta izin keluar.Sedangkan menyontek ketika kuis/ulangan dari pertemuan 1 ke pertemuan 2 tetap tetapi dari pertemuan 2 ke 3 menurun.

Kendala-kendala yang terjadi pada siklus I sudah mengalami pengurangan pada siklus IIseperti 1). Peserta didik yang berani tampil sebagai pembicara pada presentasi didepan kelas sudah mengalami pergeseran tidak lagi didominasi oleh peserta didik yang tergolong pintar.2) Alokasi waktu yang kurang tidak terjadi lagi.3)Peserta didik mulai lebih berani bertanya, menjawab maupun menanggapijawaban peserta didik lain. 4) Peserta didik yang mentertawakan temannya yang bertanya atau tampil sebagaipembicara persentasi.

Data hasilpengamatan aktivitas belajar peserta didik, diketahui bahwa secara umum terjadi peningkatan aktivitas positif dan penurunan aktivitas negatif. Berdasarkan hasil analisis data diketahui bahwa aktivitasbertanya, menjawab dan menanggapi jawaban pertanyaan masih tergolong rendah walaupun ada peningkatan dibanding siklusI. Aktivitas belajar peserta didik yang sudah tergolong baik atau bahkan sangat baik adalah aktivitas terlibat diskusi dengan teman, mengerjakan lembaran ahli, dan mencatat kesimpulan materi pelajaran.

Aktivitas negatif yang sangat signifikan penurunannya adalah berbicara dengan teman, mengerjakan tugas lain, melihat HP, dan minta izin keluar kelas.Sedangkan aktivitas menyontek saat kuis dari pertemuan 1 ke pertemuan 2 menurun tetapi dari pertemuan 2 ke pertemuan 3 tetap. Untuk itu guru harus selalumemotivasi 
peserta didik bahwa menyontek saat ujian tidak bagus dan akan merugikan dirinya sendiri, seperti tidak jujur, tidak mandiri dan tidak akan mendapatkan kepuasan batin.

Hasil belajar peserta didik dilihat darinilai rata-rata tes akhir 76,5 (tujuh puluh enam koma lima), jumlah peserta didik yang mencapai ketuntasan sebanyak17 orang $(85 \%)$ dan yang belum tuntas 3 orang (15\%).Hasil ini menunjukkan bahwa ketuntasan belajar secara klasikal tercapai, sebab lebih dari $75 \%$ peserta didik mencapai KKM.

Nilai rata-rata hasil belajar peserta didik kelas $\mathrm{IX}_{\mathrm{A}}$ pada siklus I adalah 75,5dengan nilai terendah 50dan nilai tertinggi 100. Sedangkan nilai rata-rata peserta didik siklus II adalah 76,5dengan nilai terendah55dan nilai tertinggi100. Dilihat dari hasil belajar pada siklus II terdapat peningkatan nilai rata-rata yang cukup signifikan dibandingkan dengan nilai rata-rata siklus I maupun keadaan awalyaitu besar peningkatannya adalah dari 68,5 (keadaan awal) menjadi 75,5(siklus I) dan 76,5. (siklus II). Apabila ditinjau dari jumlah peserta didik yang tuntas belajarnya juga meningkat, yaitu $65 \%$ pada keadaan awal, $80 \%$ pada siklus I dan $85 \%$ pada siklus II.

\section{Pembahasan}

\section{Aktivitas Peserta Didik}

Aktivitas-aktivitas positif peserta didik mengalami peningkatan dari siklus I ke siklus II, sedangkan aktivitas negatif mengalami penurunan.Perbandingan aktivitas-aktivitas peserta didik pada siklus I dan siklus II adalah sebagai berikut:

Tabel 9. Rekapitulasi Aktivitas Positif dan Negatif

\begin{tabular}{|c|c|c|c|c|}
\hline No & Aktivitas Peserta Didik & $\begin{array}{l}\text { Rata-rataSiklus } \\
\text { I (\%) }\end{array}$ & $\begin{array}{l}\text { Rata-rata } \\
\text { Siklus II (\%) }\end{array}$ & $\begin{array}{l}\text { Peningkatan/ } \\
\text { Penurunan }(\%)\end{array}$ \\
\hline \multicolumn{5}{|c|}{ Aktivitas positif } \\
\hline 1 & Terlibat diskusi & 78,3 & 83,3 & $+5,0$ \\
\hline 2 & Membaca/membuat lembar ahli & 83,3 & 93,3 & $+10,0$ \\
\hline 3 & Bertanya & 25,0 & 28,3 & $+3,3$ \\
\hline 4 & Menjawab & 25,0 & 28,3 & $+3,3$ \\
\hline 5 & Menanggapi & 21,7 & 26,7 & $+5,0$ \\
\hline 6 & Mencatat kesimpulan pelajaran & 90,0 & 95,0 & $+5,0$ \\
\hline & Rata-rata & 53,9 & 59,2 & $+5,3$ \\
\hline \multicolumn{5}{|c|}{ Aktivitas negatif } \\
\hline $\mathbf{1}$ & Berbicara dengan teman & 13,3 & 8,3 & $-5,0$ \\
\hline 2 & Mengerjakan tugas lain & 5,0 & 5,0 & 0,0 \\
\hline 3 & Melihat HP & 5,0 & 3,3 & $-1,7$ \\
\hline 4 & Minta izin keluar kelas & 10,0 & 5,0 & $-5,0$ \\
\hline \multirow[t]{2}{*}{5} & Menyontek saat kuis/ulangan & 13,3 & 13,3 & 0,0 \\
\hline & Rata-rata & 5,8 & 5,2 & $-0,6$ \\
\hline
\end{tabular}

Ket: Tanda (+) menunjukkan peningkatan persentase Tanda (-) menunjukkan penurunan persentase

Model pembelajaran kooperatif (Cooperative Learning) adalah rangkaian kegiatan belajar yang dilakukan peserta didik dalam kelompok-kelompok tertentu untuk mencapai tujuan pembelajaran yang telah dirumuskan. Ada empat unsur penting dalam model pembelajaran kooperatif yaitu: (1) adanya peserta didik dalam kelompok; 
(2) adanya aturan kelompok; (3) adanya upaya belajar setiap anggota kelompok, dan (4) adanya tujuan yang harus dicapai (Lie:2002).Peningkatan persentase pada aktivitas positif artinya ada perubahan kearah yang lebih baik, sedangkan penurunan persentase pada aktivitas negatif artinya adanya perubahan kearah yang lebih baik juga. Berdasarkan tabel 9 dapat dijelaskan bahwa secara umum aktivitas positif peserta didik mengalami peningkatan, walaupun peningkatannya tidak terlalu besar. Ini berarti penerapan model pembelajaran kooperatif tipe Jigsaw dapat meningkatkan aktivitas belajar peserta didik.Aktivitas negatif peserta didik juga mengalami perbaikan.Hal ini dapat dilihat dari penurunan persentasenya.Ini berarti penerapan pembelajaran kooperatif tipe Jigsawdapat memperbaiki sikap peserta didik kearah yang lebih baik.Selama proses pembelajaran,peserta didik diharapkan mempunyai aktivitas belajar positif. Menurut Sriyono (1992: 8) dalam dunia pendidikan keaktifan belajar merupakan tuntutan logis dari pengajaran yang seharusnya, tidak ada suatu kegiatan belajar mengajar tanpa melibatkan keaktifan peserta didik. Keaktifan peserta didikdalam proses pembelajaran sangat bergantung pada dorongan atau motivasi yang timbul baik dari dalam diri maupun dari luar dirinya, sehingga semakin tinggi dorongan yang timbul dalam diri seseorang peserta didik akan semakin aktif ia dalam belajar.

Tes kecil atau kuis adalah tes yang diberikan kepada peserta didik setelah proses belajar mengajar berlangsung yang terdiri dari dua atau tiga buah soal yang bertujuan untuk melihat tingkat penguasaan peserta didik terhadap materi yang disampaikan (Suharsimi Arikunto, 1997: 54).Tes semacam ini sering disebut kuis yang dimaksud untuk mengecek pemahaman peserta didik tentang materi yang baru diberikan atau juga dapat digunakan untuk materi yang akan diberikan. Seperti yang dikemukakan oleh Sujono (1988: 135) bahwa "Ruang lingkup suatu tes itu bisa sangat terbatas, hanya meliputi satu atau dua topik dan mungkin hanya berlangsung dalam waktu yang singkat, mungkin 5 atau 10 menit. Tes semacam ini biasa disebut kuis atau ulangan, yang sering kali hanya terdiri atas satu pertanyaan atau mungkin beberapa buah pertanyaan sederhana".

Hasil Belajar peserta didik dilihat dari nilai tes akhir serta persentase ketuntasan siklus I dan siklus II diperoleh data sebagai berikut:

Tabel 10. Hasil Belajar dan Ketuntasan Kelas $I_{X_{B}}$

\begin{tabular}{llcccc}
\hline No & \multicolumn{1}{c}{ Tahapan Tindakan } & $\begin{array}{c}\text { Nilai } \\
\text { Tertinggi }\end{array}$ & $\begin{array}{c}\text { Nilai } \\
\text { Terendah }\end{array}$ & $\begin{array}{c}\text { Nilai } \\
\text { Rata-rata }\end{array}$ & $\begin{array}{c}\text { Ketuntasan } \\
(\%)\end{array}$ \\
\hline $\mathbf{1}$ & Keadaan awal & 90 & 40 & 65,0 & 70,0 \\
$\mathbf{2}$ & Siklus I & 100 & 50 & 75,5 & 80,0 \\
$\mathbf{3}$ & Siklus II & 100 & 55 & 76,5 & 85,0 \\
\hline
\end{tabular}

Hasil belajar peserta didik dapat dilihat dari rata-rata yang diperolehnya.Berdasarkan tabel 10, terlihat bahwa nilai rata-rata peserta didik mengalami peningkatan dan ketuntasan belajar siswa sudah mencapai $85 \%$.Untuk lebih mudah melihat perkembangan hasil belajar peserta didik dari keadaan awal, siklus I dan siklus II dapat dilihat pada gambar berikut ini. 


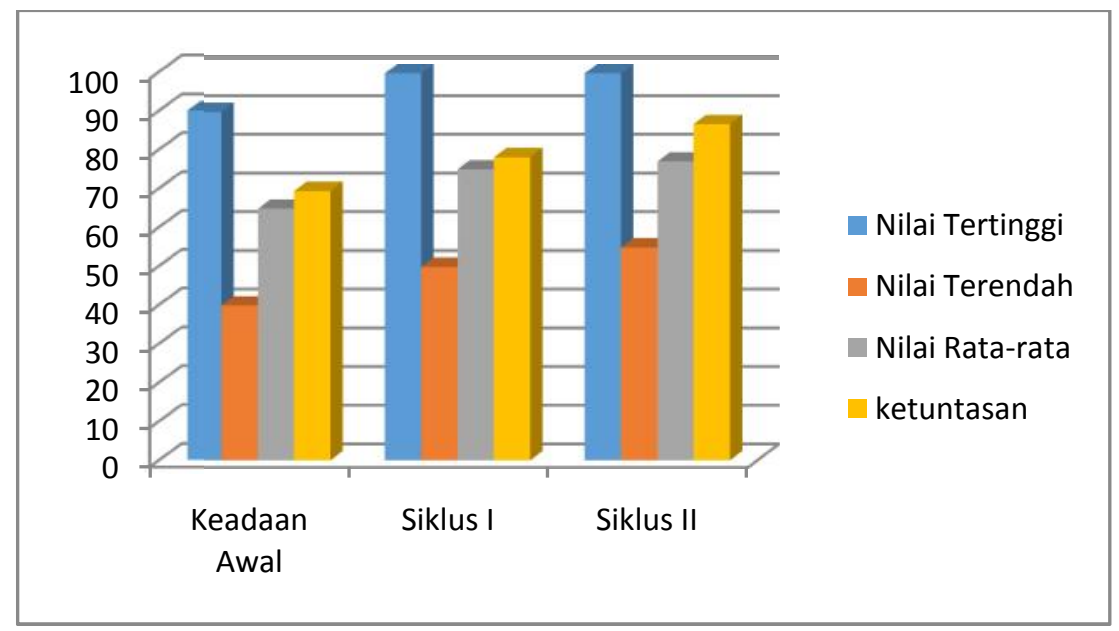

Gambar9.Grafik Nilai dan Ketuntasan Belajar Kelas $\mathbf{I X}_{\mathrm{A}}$

\section{SIMPULAN DAN SARAN}

Berdasarkan hasil penelitian dan pembahasan, maka dapat diambil disimpulkan bahwaproses pembelajaran dengan menerapkan model pembelajaran kooperatif tipe Jigsaw dapat meningkatkan aktivitas belajar peserta didik kelas $\mathrm{IX}_{\mathrm{A}}$ SMPN 2 Palupuh pada mata pelajaran Pendidikan Agama Islam.Proses pembelajaran dengan menerapkan model pembelajaran kooperatif tipe Jigsaw dapat meningkatkan motivasi dan pemahaman peserta didik kelas IX $_{\mathrm{A}}$ SMPN 2 Palupuh terhadap materi Pendidikan Agama Islam tentang "Iman kepada Hari Akhir dan Iman kepada Qada dan Qadar'.Proses pembelajaran dengan menerapkan model pembelajaran kooperatif tipe Jigsaw dapat meningkatkan hasil belajarpeserta didik kelas IX $_{\mathrm{A}}$ SMPN 2 Palupuh mata pelajaranPendidikan Agama Islam.

Berdasarkan kesimpulan yang ada, maka saran yang dapt diberikan terkait penelitian ini adalahsebaiknya guru Pendidikan Agama Islamdapat memilih materi pembelajaran sesuai dengan model pembelajaran kooperatif (cooperative learning)tipe Jigsaw.Sebaiknya dilakukan pula penelitian dengan menerapkan model pembelajaran cooperative learningtipe Jigsawpada kelas $\mathrm{IX}_{\mathrm{B}}$ ataupun kelas lainsupaya aktivitas dan hasil belajarnya meningkat.

\section{DAFTAR RUJUKAN}

Corey, S.M. (1994). Action Research, Fundamental Research and Educational Practises. Teacher's College Record.

Corey, S.M. (19955). Action Research by Teacher and Population SamplingProblems. Journal of Education Psychology.

Fathurrahman.P (2007). Strategi Belajar Mengajar. Bandung: PT Refika Aditama.

Festiyed . (2001). Penelitian Tindakan Kelas Fisika. UNP.

Fitra Netti (2010). Penelitian Tindakan Kelas. Candung: SMPN 2 Candung

Hopkins, D. (1993). A Teacher's Guide to Classroom Research. Edition. Philadeephia: Open University Press.

Kemmis, S. (1982). Action research in retrospect and prospect pedagogy. Geelong: Deakin University.

Mc. Taggart, M. (1993). Action research and parent participation. Contradictions,

Concerns and Consequences, Curriculum Perspectives. 
Muhammad Rohman, dkk (2013). Strategi \& Desain Pengembangan Sistem Pembelajaran, Jakarta: Prestasi Pustakaraya.

Raka Joni, T. (1998). Penelitian Tindakan Kelas: Beberapa Permasalahannya. Jakarta: PCP PGSM Ditjen Dikti. Rusman (2012). Model-Model Pembelajaran, Jakarta: PT Raja Grafindo Persada. 